\title{
Improving Crop Lodging Resistance by Adjusting Plant Height and Stem Strength
}

\author{
Yanan Niu ${ }^{1}$, Tianxiao Chen ${ }^{1}$, Chenchen Zhao ${ }^{1}$ and Meixue Zhou ${ }^{1,2, *(\mathbb{D})}$ \\ 1 Tasmanian Institute of Agriculture, University of Tasmania, Private Bag 1375, Prospect, TAS 7250, Australia; \\ yanan.niu@utas.edu.au (Y.N.); tianxiao.chen@utas.edu.au (T.C.); chenchen.zhao@utas.edu.au (C.Z.) \\ 2 College of Agronomy, Shanxi Agricultural University, Jinzhong 030801, China \\ * Correspondence: meixue.zhou@utas.edu.au
}

Citation: Niu, Y.; Chen, T.; Zhao, C.; Zhou, M. Improving Crop Lodging Resistance by Adjusting Plant Height and Stem Strength. Agronomy 2021, 11, 2421. https://doi.org/10.3390/ agronomy11122421

Academic Editor: Jane K. Dever

Received: 30 October 2021

Accepted: 26 November 2021

Published: 27 November 2021

Publisher's Note: MDPI stays neutral with regard to jurisdictional claims in published maps and institutional affiliations.

Copyright: (c) 2021 by the authors. Licensee MDPI, Basel, Switzerland. This article is an open access article distributed under the terms and conditions of the Creative Commons Attribution (CC BY) license (https:/ / creativecommons.org/licenses/by/ $4.0 /)$.

\begin{abstract}
Crop height not only determines plant resistance to lodging and crowding, but also affects crop architecture, apical dominance, biomass, and mechanical harvesting. Plant height is determined by the internode elongation, regulated by genes involved in gibberellin (GA) and brassinosteroid (BR) biosynthesis or related signaling networks. Plants' genetic inability to synthesize or respond to GAs and BRs induce dwarfness. However, the signaling mechanisms of GAs and BRs for controlling plant height individually or collectively are still unclear. Since stem mechanically supports plant during the whole life span, components that affect stem physical strength are also important to crop lodging resistance. One of the major components is lignin, which forms stem structure, thus contributing to crop lodging resistance. In this review, we looked into the reported genes involved in lignin, GAs, and BRs biosynthesis and summarized the signaling networks centered by these genes. Then, we filled the knowledge gap by modifying plant height through interrupting normal GA and BR metabolism utilizing core gene inhibitors. Therefore, we highly endorsed the current approaches of using plant growth regulators (PRGs) to maintain an ideal plant height under lodging stress, and proposed possibilities of modifying crop culm strength against lodging as well.
\end{abstract}

Keywords: lodging resistance; plant height; GAs; BRs; lignin; PRGs

\section{Introduction}

Lodging refers to a permanent displacement of crops, stems or roots from their vertical orientation under unfavorable weather or soil conditions [1]. Therefore, lodging in cereals can be divided into stem lodging and root lodging [2,3]. Plant height is associated with stem lodging [4-6]. The final height of a plant is determined by internode elongation, which is regulated by genes involved in gibberellin (GA) and brassinosteroid (BR) biosynthetic or signaling pathways. As the two major plant hormones are involved in modulating diverse processes throughout plant growth and development, inadequate Gas and BRs biosyntheses lead to a dwarf or semi-dwarf stature, resulting in increased lodging tolerance [7-12]. In addition, interactions between GAs and BRs also regulate plant growth and development, but were not highlighted $[13,14]$.

Plant growth regulators (PGRs) mainly function by regulating plant hormone biosynthesis, including GAs and BRs, or related signal transductions in cereal crops for maintaining targeted agronomic traits, such as crop height to secure cereal yield. Even though an increasing number of PGRs are being applied for multiple agricultural purposes, the most common purpose is still to reduce crop height [15].

The biochemical characteristics of stems, such as cellulose, hemicellulose, lignin, silica, and soluble sugar contents, which are classified as structural carbohydrates (SC), significantly contribute to stem physical strength against lodging stress. Low lignin or cellulose contents in the stem result in brittleness of culm of plants, such as Arabidopsis [16], rice [17,18] and buckwheat [19] and lodging-resistant varieties show more lignin accumulation than lodging-susceptible ones [20-22]. 
GAs, BRs and lignin pathways have been subjected to intensive studies in Arabidopsis, but the genes and orthologs or homologs involved in the biosynthetic or signaling processes have not been fully discovered in major staple crops, such as rice, wheat, barley, and maize.

\section{Biosynthetic Pathways Involved in Plant Height Regulation}

\subsection{GA Biosynthesis or Signaling Pathways}

Gibberellins (GAs) play an important role in modulating diverse processes throughout plant growth and development, mainly stem elongation. Internode elongation is an important agronomic trait that determines final culm length, panicle exertion, and crop biomass [23]. Ample evidences from rice, barley, and Arabidopsis mutants indicate a common mechanism that internode elongation is regulated by genes involved in gibberellin (GA) and brassinosteroid (BR) biosynthetic or signaling pathways [24]. This can be evidenced either by mutants with decreased bioactive GA concentrations which leads them to be dwarf or semi-dwarf in stature, or elevated bioactive GA concentrations which leads to increased crop height [7]. Semi-dwarf rice mutants with gibberellic acid (GA)-deficiency or GA-insensitivity are more tolerant to lodging stress under extreme environmental conditions, indicating that lodging tolerance can be increased by decreasing plant height through phytohormone GA accumulation [8,9]. Due to the property of being short-statured, plants lacking GAs displayed higher bending-type lodging resistance but lower breaking-type lodging resistance [25].

Three main stages are involved in the isoprenoid pathway leading to GA biosynthesis (Figure 1) [26,27]. The first stage starts with mevalonic acid and other metabolites (Figure 1). Isopentenyl diphosphate (IPP), farenesyl pyrophosphate (FPP) and geranylgeranyl pyrophosphate (GGPP) are the key intermediates, which are also precursors for cytokinin, abscisic acid (ABA), sterol, terpenoid and carotenoid biosynthesis [26,28]. The second stage is a series of oxidation reactions that generate GA12-aldehyde, which is a specific intermediate for GA formation (Figure 1). The final step is the synthesis of active GAs, which is the catalysation of 2-oxoglutarate-dependent dioxygenases, including 20-oxidase (20ox) and 3-oxidase (3ox) (Figure 1). The enzymes involved in this process are listed in Figure 1.

The first characterization of a GA-biosynthetic mutation was reported in maize, in which dwarf-5 mutant was defective in ent-kaurene synthase (KS) activity, producing entisokaurene rather than ent-kaurene [29]. Two cytochrome P450 genes, CYP714B1 and CYP714B2, encode GA 13-oxidases, which plays a role in fine-tuning plant growth by decreasing GA bioactivity, and overexpression of these two genes in rice induced semidwarfism [30]. Correspondingly, most mutants or knockdown lines of GA biosynthesis genes, including CPS (ent-copalyl diphosphate synthase), KS, KAO (ent-kaurenoic acid oxidase), $K O$ (ent-kaurene oxidase), GA20oxs, and GA3oxs, also exhibit dwarfism phenotypes, which results in improved lodging resistance, a valuable trait for rice breeding [31,32]. However, some mutants become extremely dwarfed, thus cannot be used in breeding programs.

Genes encode 20-oxidase in GA biosynthetic pathways were identified in various cereal crops, affecting the later steps in GA biosynthetic pathway, thereby reducing plant height. For example, rice $s d-1$ mutants and $s d w 1$ (HvGA20ox2) allele in barley have loss-of-function mutations in the GA synthesis gene, GA 20 oxidase2 (semi dwarf-1; SD-1) [33,34], while wheat Reduced height-1 (Rht-1) mutants have gain-of-function mutations in a gene encoding a suppressor of a GA signal known as the DELLA protein [35]. The wheat Green Revolution genes, Rht-B1b (Rht1) and Rht-D1b(Rht2), are orthologues of the Arabidopsis gibberellic acidinsensitive (gai) [36], the maize dwarf-8 (d8) [37], the rice OsGAI also known as SLR1 [38,39], and the barley slender1 $(s \ln 1)$ genes [40]. A 17-amino acid deletion affecting the DELLA region resulted in GA-insensitive dwarf rice phenotypes [38], which are similar to that in the gai mutant of Arabidopsis [41]. 


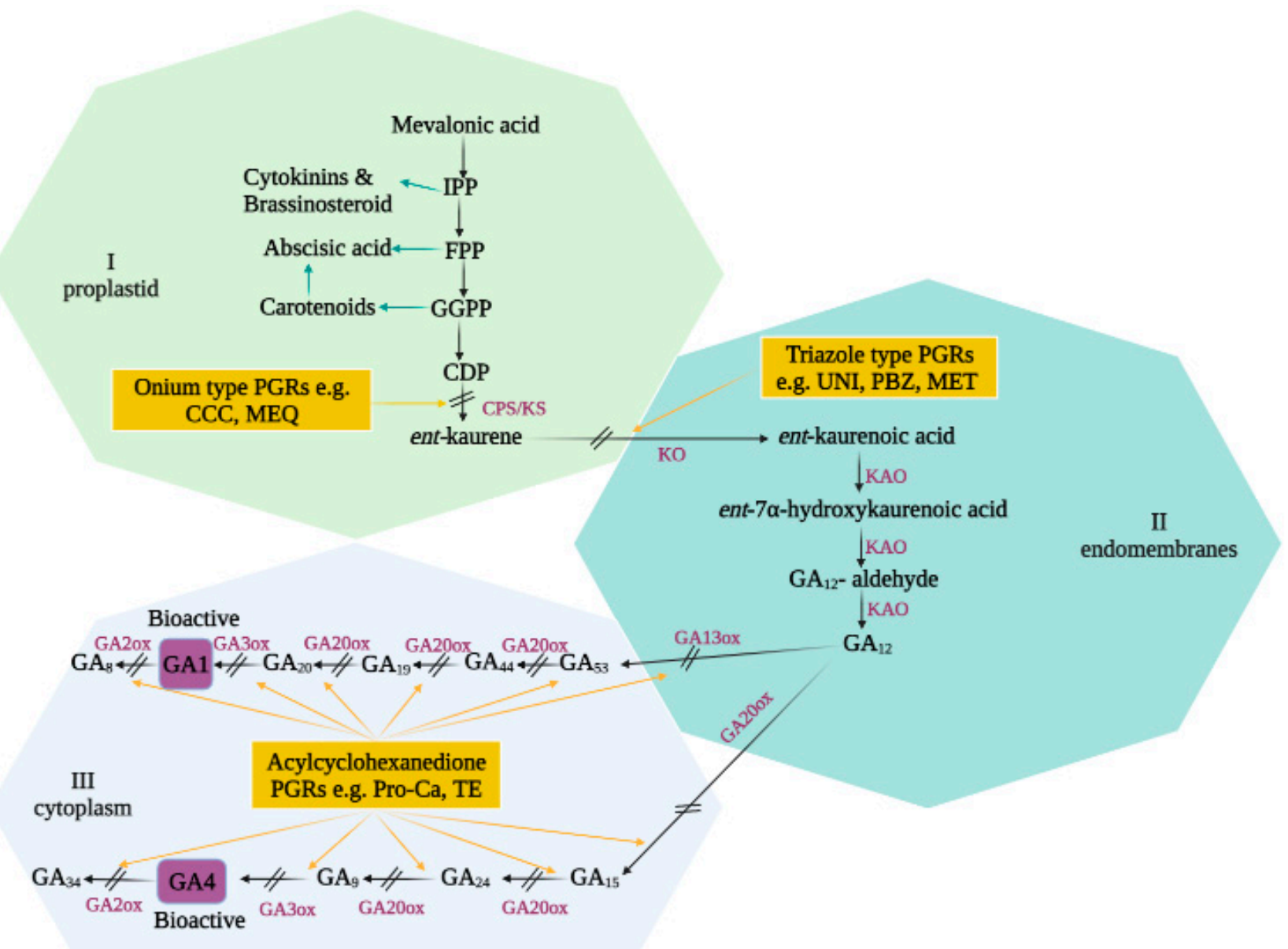

Figure 1. GA biosynthetic pathways in cereals. The respective enzymes involved in this process are in purple. Arrows with oblique lines show the inhibition of PGRs. Anti-GA PGRs are in the yellow rectangle. Blue arrows show the crosstalk with other plant hormones. IPP: Isopentenyl diphosphate; FPP: Farenesyl pyrophosphate; GGPP: Geranylgeranyl pyrophosphate; CDP: ent-Copalyl diphosphate; CPS: ent-copalyl diphosphate synthase; KS: ent-kaurene synthase; KO: ent-kaurene oxidase; KAO: ent-kaurenoic acid oxidase.

As GA positively regulates the diameter of culm internodes and lignin content, it improves lodging resistance in two perspectives in rice; structurally, by increasing culm diameter, and qualitatively, by increasing lignin content [25]. Compared to BR, GA has a relatively minor role in promoting coleoptile and root elongation in rice [42]. Exogenous GA greatly promoted leaf sheath elongation in rice, resulting in sheaths that were up to 4-fold longer than those not treated with GA [43].

Overproducing GA 2 oxidase (GA-inactivating enzyme) exhibited increased tillering by negatively regulating expression of OS TEOSINTE BRANCHED1 (OsTB1), a positive regulator for strigolactone signaling [44]. The ABA compound can be produced directly from FPP or indirectly from the conversion of GGPP to carotenoids, and cytokinin compound can be produced directly from IPP (Figure 1) [26]. Inhibited GA-inducible responses by ABA, such as the expression of $\alpha$-amylase by regulating WRKY transcription factors, are also reported in rice [45]. Commercial PGRs, such as chlormequat (CCC) and mepiquat (MEQ), which are also defined as onium-type PGRs, have been found to decrease height and increase stem diameter in cereals by blocking the activity of specific enzymes involved in GA biosynthesis (Figure 1) [27,28]. PBZ (paclobutrazol) and UNI (uniconazole), which are classified as triazole compounds, are highly efficient in binding and inactivating enzymes 
involved in the conversion of ent-kaurene to ent-kaurenoic acid (Figure 1) [27]. Acylcyclohexanedione PGRs such as Pro-Ca (prohexadione-calcium) and TE (trinexapac-ethyl) have a similar structure to 2-oxoglutaric acid, therefore inhibit the formation of activated GA (Figure 1) [27,46,47].

\subsection{BR Biosynthetic or Signaling Pathways}

Brassinosteroids (BRs) are a class of steroidal phytohormones that play an essential role in regulating diverse processes during the whole life cycle of plants and plants' adaptation to abiotic stresses $[48,49]$. Based on the total number of carbons, BRs are divided into C27, C28, and C29-type. Three pathways of BR biosynthesis leading to the production of C27-, C28-, or C29-type of BRs are currently known in Arabidopsis thaliana [50] (Figure 2). Early steps of their synthesis are common for each type and may occur via a mevalonate (MVA) or non-MVA pathway, while later steps differentiate BR biosynthesis pathways [51]. The direct pathway is $\mathrm{C}_{27}$-BRs, from IPP to cholestanol, and then to 28-norBL (Figure 2). The biosynthesis of $\mathrm{C}_{29}$-BRs is initiated from $\beta$-sitosterol and leads to 28-homoBL (Figure 2). $\mathrm{C}_{28}$-BRs biosynthesis pathway starts from episterol to sampesterol, and then goes to $\mathrm{C}_{28}$ BRs (Figure 2). The last step in the transformation of castasterone (CS) to BRs is not clear in the dicotyledons (Figure 2). So far, most of the reactions, enzymes, and genes have only been discovered and characterized by the $\mathrm{C}_{28}$-BR biosynthesis pathway in Arabidopsis thaliana, while fewer genes were isolated in cereals [52].

Several components of the BR signaling pathway in rice, such as OsBRI1 (BrassinosteroidInsensitive1) [53], OsBAK1 (BRI1-Associated receptor Kinase1) [54] form a core of the transmembrane BR receptor complex, OsGSK1 and OsGSK2 (Glycogen Synthase Kinases) [55]. The complex is a major negative regulator of BR signaling, and OsBZR1 (Brassinazole-Resistant1) transcription factor plays a pivotal function in BR-dependent regulation of gene expression [56]. BR-deficient mutants usually display decreased leaf length, erect leaves, reduced plant height, and shortened roots, and exogenous BR application could have inhibitory effects on rice growth and development [42]. Mutations in the OsBRI1 gene (d61) in rice were loss-of-function mutations. The mutants showed semi-dwarfism, erect stature and BR insensitivity [10,11]. Overexpressing the wheat TaBRI1 gene in Arabidopsis led to faster germination, early flowering, and higher seed yield [57]. In barley, a series of alleles of the homologous gene, $H v B R I 1$, has been identified. One of the alleles, uzu1.a, is a well-known semi-dwarfing allele in Northeast Asian short-culm cultivars and landraces [58]. A loss-offunction mutation of the OsBAK1 gene results in erect leaves and the BR insensitivity, but without any significant effect on plant height, reproduction and grain yield [11]. In wheat, the homologs of OsBAK1 are the SERK family proteins. Functional analysis indicated that TaSERK genes in Arabidopsis led to increased height and seed yield [59].

On the other hand, mutants or transgenic rice plants with enhanced BR levels or BR signaling have been observed to display reduced plant height. For example, CYP724B1/D11 is involved in the brassinosteroid biosynthesis pathway [60], BRASSINOSTEROID UPREGULATED1(BU1) overexpressor (Tanaka et al., 2009) [61], BAK1 and [62], DWARF AND LOW-TILLERING (DLT) overexpressor, which work in the signal transduction pathway [63]. Evidence has also been found in Arabidopsis with low concentrations of BR promoting the growth of both the root and hypocotyl, whereas high concentrations of BR inhibit root growth but still promote hypocotyl growth (Müssig et al., 2003). Similarly, in rice, $\mathrm{BR}$ significantly promotes coleoptile growth, but a relatively higher concentration of BR inhibits both root and seedling growth (Tong et al., 2009). HvD1(Brh1) and HvDEP1 are two barley genes encoding the $\alpha$-subunit and $\gamma$-subunit of the heterotrimeric $G$ protein, respectively. $H v D 1(B r h 1)$ caused a semi-dwarf phenotype, but did not show any major negative impact on malting quality, which is a very important trait in barley breeding [12]. Loss of function in a cytochrome P450 (CYP90B2) involved in BR biosynthesis in rice was detected in the Osdwarf4-1 mutant which exhibits erect leaves and slight dwarfism without compromising grain yield [64]. 


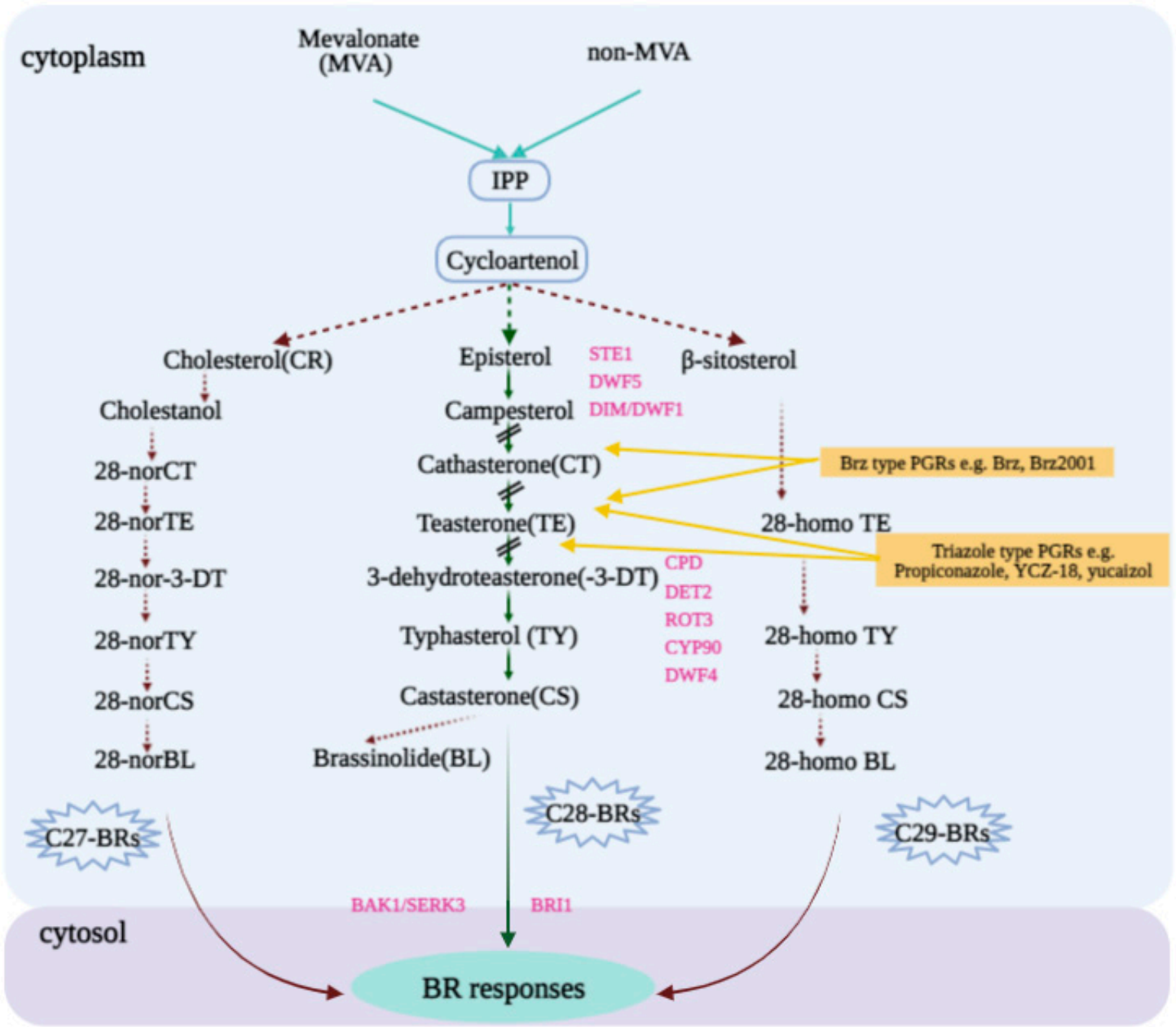

Figure 2. Brassinosteroid synthesis pathway in cereals. Blue lines are the common steps both for cereals and Arabidopsis, brown lines show the steps in Arabidopsis, and green lines show the steps found in cereals. The respective enzymes involved in this process are in purple. The final product of the pathway is Castasterone (CS). Green arrows with oblique lines show the inhibition of PGRs. Anti-GA PGRs that inhibit steps are shown in the yellow rectangle. IPP: Isopentenyl diphosphate; STE1: $\Delta^{7}$-sterol-C5-desaturase; DWF5: $\Delta^{5,7}$-sterol- $\Delta^{7}$-reductase; DIM/DWF1: $\Delta^{5}$-sterol- $\Delta^{24}$-reductase; DWF4: C-22 hydroxylase; DET2: $5 \alpha$ reductase; CPD: C-23 $\alpha$-hydroxylase/C-3 dehydrogenase; ROT3 and CYP90D1: C-23 hydroxylases; BR6ox1: brassinosteroid-6-oxidase 1; BR6ox2: brassinosteroid-6-oxidase 2.

BRs also interact with other phytohormones to regulate plant growth and development [13]. An early study found that BRs and GAs act antagonistically to regulate the expression of a GA-responsive gene, GASA1 (for GA-stimulated transcript in Arabidopsis), as well as a GA biosynthetic gene, GA5 (GA20ox) [14]. In another study, BR was found to induce several GA biosynthetic genes, including GA20ox-1, GA20ox-2, and GA20ox-5, in Arabidopsis [65]. GA-deficient or GA-insensitive mutants are sensitive to BR, whereas a mutant lacking DELLA proteins has greatly enhanced BR sensitivity [66].

The rice $D 1$ gene encodes heterotrimeric G-protein alpha subunit (RGA1) which functions in several signaling pathways [67]. Mutations in the D1 gene lead to characteristic BR-specific phenotype, including reduced height and erect leave. It is also known that mutations in the OsD1/RGA1 gene affect GA signal transduction and disease resistance [68], thus OsD1/RGA1 is involved in crosstalk between the BR and GA signaling pathways [11]. Rice BR-GA hormonal crosstalk is evidenced by the fact that OsBZR1 directly binds to promoters of the GA20ox-2, with GA3ox-2 (GA biosynthetic genes) greatly inducing their expression and GA2ox-3 (GA inactivation gene) repressing its transcription [49]. SPINDLY 
participates in both BR and GA responses, thus it regulates the elongation of lower internodes of rice [69]. However, in rice root, BR application appears to repress the levels of active GA by inhibiting the expression of GA20ox-3, a GA biosynthetic gene, and by simultaneously promoting the expression of GA2ox-3, a GA inactivation gene [70]. Generally, BR promotes GA biosynthesis and inhibits GA inactivation, while GA extensively inhibits $B R$ biosynthesis and BR response as a feedback mechanism in rice [42,70]. Overexpression of OsIAA1 in rice, which is a member of the Aux/IAA family proteins, results in reduced auxin sensitivity but increased sensitivity to BR [71]. In a previous study, Liu et al. [72] summarized the dwarf genes involved in interactions between the other relevant dwarfing phytohormones, which facilitates our understanding of crosstalk between different hormone pathways.

So far, 17 inhibitors for BR pathway-KM-01, brassinozole (Brz), Brz2001, Brz220, propiconazole, YCZ-18, yucaizol, fenarimol, spironolactone, triadimefon, imazalil, 4-MA, VG106, DSMEM21, finastride, AFA76, and brassinopride-have been discovered in Arabidopsis thaliana [73]. Inhibitors used in the $\mathrm{C}_{28}$-BRs biosynthesis pathway are Brz, Brz2001, Brz220, propiconazole, YCZ-18, yucaizol, and fenarimol [52] (Figure 2). The chemical structure of Brz is similar to triazole-type PGRs such as UNI and PBZ, which block the conversion of campestanol to TE, and Brz2001 has the same function as Brz [74]. The triazole compound, propiconazole, blocks the same reactions with Brz, and YCZ-18 and yucaizol bind to the CYP90D1 enzyme and inhibit the BR-induced cell elongation [75]. Other PGRs such as fenarimol inhibit the conversion of CT to TE [76].

These results provide strategies for genetic improvement and field management of crop production by modulating BR biosynthesis and signal transduction, and the crosstalk of other hormones. With a better understanding of the hormonal regulation of culm elongation, a similar strategy would also be possible for other components in BR biosynthesis and signaling pathways.

\subsection{Lignin Biosynthesis Mechanism}

The biochemical pathways of monolignol biosynthesis are highly conserved throughout vascular plants, and most current research has focused on monolignol biosynthesis. However, although a majority of enzymes in the monolignol biosynthesis pathway have been identified and characterized, additional pathway components cannot be ruled out [77]. It is well known that peroxidases and laccases are involved in dimerization and cross-linking of monolignols, but more detailed mechanisms have yet to be unveiled [78]. Moreover, multifunctional enzymes involved in lignin biosynthesis pathways also correspond to diverse gene families, such as COMT, which can be used as an elicitor-induced plant defense response, and $\mathrm{F} 5 \mathrm{H}$ which acts as a cytochrome-P450-dependent monooxygenase [77]. Hence, it is a big challenge to explore the molecular mechanism behind the lignin biosynthesis pathways.

Phenylalanine ammonia lyase $(P A L)$, cinnamate 4-hydroxylase $(C 4 H)$, 4-coumaroyl-CoA ligase (4CL), chalcone synthase (CHS), caffeoyl-CoA 3-O-methyltransferase (CCOAOMT), and hydroxycinnamoyl transferase $(H C T)$ are key genes in the biotechnological alteration of lignin biosynthesis to improve wood properties $[79,80]$. Similarly, in wheat, CoA ligase 1 (4CL1), cinnamoyl-CoA reductase2 (CCR2), $\varrho$-coumarate 3-hydroxylase1 (C3H1), ferulate 5-hydroxylase2 ( $F 5 H 2)$, and caffeic acid O-methyltransferase2 (COMT2) were highly expressed in wheat tissues, indicating the significance of these genes in the intervening lignin accumulation in wheat culm [81] (Figure 3). 


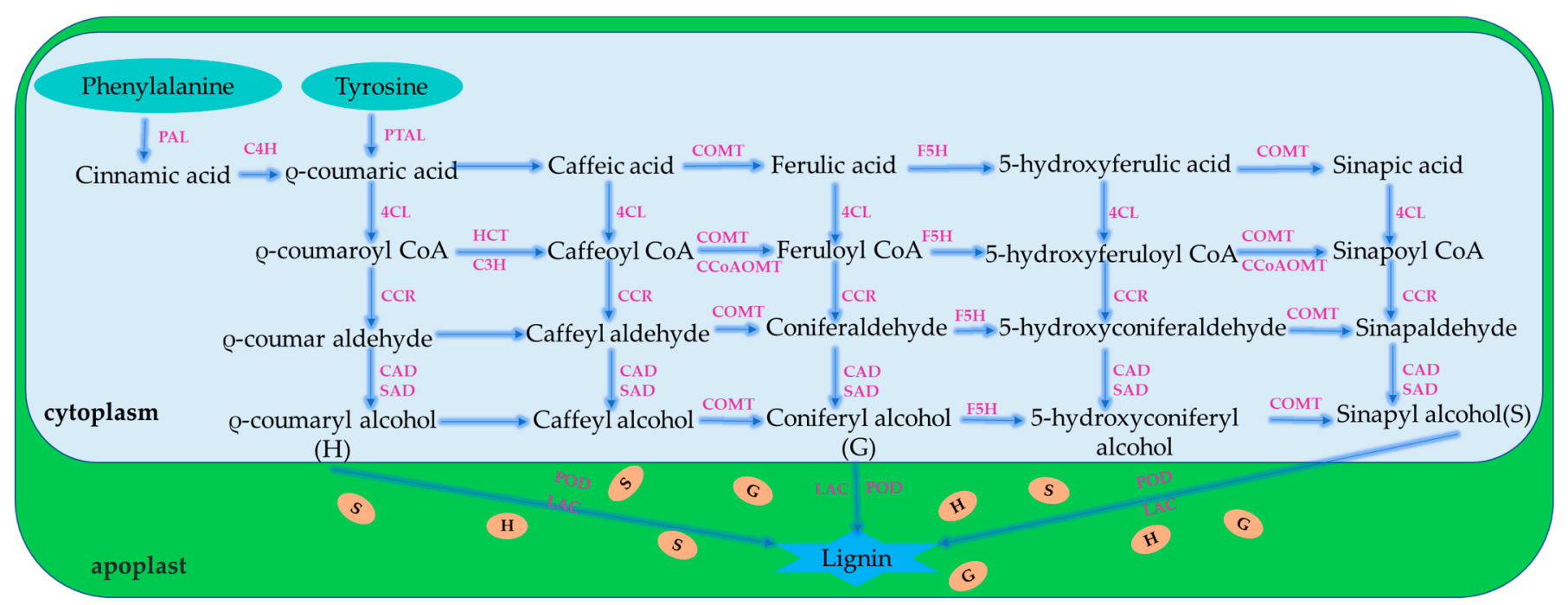

Figure 3. Lignin biosynthetic pathway in cereals. Enzymes involved in this pathway include $P A L, P T A L, C 4 H, 4 C L, H C T$, $C 3 H, C O M T, C C O A O M T, C C R, C A D, F 5 H, P O D$ and $L A C$. The respective enzymes involved in this process are in purple. PAL: phenylalanine ammonia lyase; PTAL/TAL: phenylalanine /tyrosine ammonia-lyase; C4H: cinnamate4-hydroxylase; 4CL: 4-coumarate: coenzyme A ligase; HCT: hydroxycinnamoyl CoA shikimate/quinate hydroxycinnamoyl transferase; C3H: P-coumarate 3-hydroxylase; COMT: caffeic acid O-methyltransferase; CCoAOMT: caffeoyl-CoA O-methyltransferase; CCR: cinnamoyl-CoA reductase; CAD: cinnamyl alcohol dehydrogenase; F5H: ferulate5-hydroxylase; POD: peroxidase; LAC: Laccase. S, G, and H stand for sinapyl alcohol, coniferyl alcohol, and $p$-coumaryl alcohol lignin units, respectively.

$C C R$ is a key gene in the lignin monomer biosynthesis pathway. Under abiotic stress condition, $C C R 1 / 2$ were significantly up-regulated in the root elongation region of maize [82]. Studies on lodging-resistant (H4546) and lodging-sensitive (C6001) wheat cultivars suggested that Ta-CCR1 [83], TaCAD1 [84], TaCCoAOMT1 [85], and TaCM [86] and their related enzymes are involved in lignin biosynthesis and are critical for lodging resistance. During the biosynthesis of lignin monomers (or monolignols), the formation of sinapyl alcohol requires the 5-O-methylation of 5-hydroxy to conifer aldehyde catalyzed by caffeate O-methyltransferase (COMT, EC 2.1.1.68) [87,88]. Similar results have been found in rice (OsCOMT1) [89,90], maize (ZmCOMT) [91], barley (HvOMT1) [91], and sorghum (SbCOMT) [92]. PALs can catalyze the lignin precursor phenylalanine and transform it into cinnamic acid in the lignin biosynthesis pathway [93]. In rice, overexpression of an $\mathrm{F} 5 \mathrm{H}$ gene $\mathrm{OsCAld5H1}$ increased the content of $\mathrm{S}$ units, while down-regulation of this gene enhanced the production of G lignin [94]. AMP-binding domain-containing 4CLs are critical enzymes in phenylpropanoid metabolism pathway with the loss of 4CL1 leading to reduced lignin content in Arabidopsis [95]. Suppression of Os4CL3 expression results in significant lignin reduction, impaired plant growth, decreased panicle fertility, and reduced height of rice [96]. OsAAE3 is a homolog of Arabidopsis AAE3 in rice, which encodes a 4-coumarate-Co-A ligase (4CL) such as protein. Over-expression of OsAAE3 resulted in a significant decrease in expressions of lignin biosynthesis genes, leading to reduced lignin content [97]. Cinnamyl alcohol dehydrogenase $(C A D)$ catalyzes the last step of monolignol biosynthesis. OsCAD2 is largely responsible for monolignol biosynthesis in rice stem, while mutant plants exhibit drastically reduced $C A D$ activity and undetectable sinapyl alcohol dehydrogenase activity $[98,99]$. In maize, a CCoAOMT gene ZmCCoAOMT2, which is associated with resistance to multiple pathogens, is involved in the biosynthesis of lignin and other phenylpropanoid metabolites and regulation of programmed cell death [100]. However, in wheat, TaCCoAOMT1 is critical for stem development but there is no evidence to show that it is directly associated with lodging-resistance [85]. Two HCT genes, HCT1806, and HCT4918, were identified in maize and regulate plant disease resistance by binding to NLR Rpl protein, which enhanced the expression of lignin biosynthesis pathway genes and lignin accumulation [101]. All of the above suggests that the lignin biosynthesis pathway 
and its related enzyme biosynthesis play a vital role in assisting plants in stronger stem strength or soil anchorage, and these traits ultimately make them tolerant to lodging stress environment.

General processes involved in the lignin biosynthesis pathway in plants have been illustrated in previous studies [102,103]. However, the functions of these genes involved in the lignin biosynthesis pathway remain unexplored in many cereal crops, such as acylcoenzyme synthetases (LACSs) [104]. A 20-40\% reduction in lignin content has been observed in knockout mutants of two laccase genes, LAC4 and LAC17 [105], and a complete loss of lignin deposition in roots has been detected in a triple mutant of LAC4, LAC11, and LAC17 in Arabidopsis [106]. Here, we present a general lignin biosynthesis pathway in cereals (Figure 3). It is extremely important to have a full understanding of lignin biosynthesis pathway, as it plays a vital role in reducing financial losses caused by internal and external factors and guiding researchers to develop better strategies for crop yield improvement.

\section{Future Perspectives}

Crop height is an important factor for lodging resistance, fundmentally affect crop yield [72]. The "green revolution", which benefited from the breeding of semi-dwarf crops, along with proper applications of fertilizer and pesticide, has greatly increased crop production $[107,108]$. While there is no doubt about the contribution of semi-dwarfing, extreme dwarfing leads to small grains, semi-sterility, malformed panicles, thus decreased yield and biomass production $[72,109,110]$. Therefore, it is necessary to exploit dwarf germplasm, and identify novel semi-dwarf genes without adverse effects on agronomic traits.

The BR-responsive module, OsmiR159d-OsGAMYBL2, acts as a common component functioning in both BR and GA pathways which connect BR signaling and GA biosynthesis, and thus coordinate the regulation of BR and GA in plant growth and development [111]. Castorina and Consonni (2020) presented a model to illustrate that BR promotes GA biosynthesis and inhibits GA inactivation, which leads to increased GA levels and cell elongation. Dwarf stature caused by mutants involved in the BR pathway is attributed to reduced internode length but not decreased internode number [112]. By binding to the promoters of GA biosynthetic genes, BR could modulate the activities of growth-related genes through the interaction with GAs. Mechanisms of BR-GA interaction in controlling plant height has been well studied both in Arabidopsis thaliana [113] and in rice [42], hence, it is worth exploring the function of BR-GA interaction in dwarfing for future applications in other cereals.

Even though dwarfing was mainly attributed to the plants' genetic inability to synthesize or respond to GAs and BRs, other hormones, including strigolactones (SLs) [114], indole-3-acetic acid (IAA) [115], and abscisic acid (ABA) [116] are also associated with crop height. Plant height is controlled by genes that formed a complex regulatory network, mainly involving the biosynthesis or signal transduction of phytohormones. Excessive focus on the application of dwarf genetic materials such as $s d 1$ and $R h t 1$ poses a high risk of losing genetic diversity. Therefore, other genes involved in the GA and BR pathways need to be exploited. It is necessary to not only understand the effect of newly identified genes in crop height, but also investigate its effect on other traits related to lodging. In addition, whether these identified genes involve GA and BR synthesis which can be utilized to optimize crop lodging should also be investigated. In addition, environmental factors such as light, temperature, water, and nutrition also need to be ascertained in order for appropriate crop height-related genes to be used in different ecological areas.

Lignins are important components of the secondary cell wall, which decide cell wall stiffness and mechanical support to the plant body, enabling plants to grow upwards $[117,118]$. To overcome the low grain production caused by dwarf plant architecture, most studies have focused on increasing plant density for securing crop production. However, severer lodging was observed under higher plant densities and this is mostly due to the lignin synthesis [119-121]. Lignin accumulation and its composition (i.e., H-, G- 
and S-type monomers) are important factors influencing the breaking strength of crop culm [121]. How plant density regulates lignin biosynthesis in the basal culm, and its relationship with lodging resistance in cereals are of great importance. A reasonable plant density is needed to decrease the risk of lodging occurring, not only by altering the basal stem morphological traits but also by modifying lignin metabolism. As lignin deposition in the plant cell walls can also be affected by environmental conditions such as biotic (bacteria, fungi and virus) and abiotic stresses (mineral deficiency, drought, ultraviolet-B (UV-B) radiation and low temperatures), and mechanical injuries, a greater understanding of lignin biosynthesis under different agricultural environments should be researched [121,122].

Lignin is the predominant cell wall polymer that significantly enhances cell wall thickness, thereby increases stem breaking force for high lodging resistance in rice [123]. Although low cellulose content along with a significant decreased cell wall thickness were observed in the dwarf barley plants, over-expression of barley secondary cell wall cellulose synthase $(\mathrm{HvCes} A)$ shows no increases in overall crystalline cellulose content or stem strength [124]. Compared with lignin biosynthesis, the individually up-regulated cellulose level in plants is likely to require more sophisticated strategies in the future. Therefore, increasing lignin level rather than cellulose or hemicelluloses becomes critical for high cell wall strength. Meanwhile, genetic modification of crop cell walls has a great potential for improving crop lodging resistance. However, we have to consider whether lignin affects crop height during the process of regulating crop resistance against lodging.

Author Contributions: Conceptualization, Y.N., T.C. and M.Z.; Visualization, Y.N. and T.C.; WritingOriginal Draft Preparation, Y.N.; Writing-Review and Editing, M.Z. and C.Z.; Supervision, M.Z.; Project Administration, M.Z.; Funding Acquisition, M.Z. All authors have read and agreed to the published version of the manuscript.

Funding: This work is funded by the Grains Research and Development Corporation (GRDC) of Australia (PROC-9175606).

Institutional Review Board Statement: Not applicable.

Informed Consent Statement: Not applicable.

Data Availability Statement: Not applicable.

Conflicts of Interest: The authors declare no conflict of interest.

\section{References}

1. Dahiya, S.; Kumar, S.; Chaudhary, C. Lodging: Significance and preventive measures for increasing crop production. Int. J. Chem. Stud. 2018, 6, 700-705.

2. Sterling, M.; Baker, C.J.; Berry, P.M.; Wade, A. An experimental investigation of the lodging of wheat. Agric. For. Meteorol. 2003, 119, 149-165. [CrossRef]

3. Hu, H.; Liu, W.; Fu, Z.; Homann, L.; Technow, F.; Wang, H.; Song, C.; Li, S.; Melchinger, A.E.; Chen, S. QTL mapping of stalk bending strength in a recombinant inbred line maize population. Theor. Appl. Genet. 2013, 126, 2257-2266. [CrossRef]

4. Verma, V.; Worland, A.J.; Savers, E.J.; Fish, L.; Caligari, P.D.S.; Snape, J.W. Identification and characterization of quantitative trait loci related to lodging resistance and associated traits in bread wheat. Plant Breed. 2005, 124, 234-241. [CrossRef]

5. Yao, J.; Ma, H.; Zhang, P.; Ren, L.; Yang, X.; Yao, G.; Zhang, P.; Zhou, M. Inheritance of stem strength and its correlations with culm morphological traits in wheat (Triticum aestivum L.). Can. J. Plant Sci. 2011, 91, 1065-1070. [CrossRef]

6. Kashiwagi, T.; Sasaki, H.; Ishimaru, K. Factors responsible for decreasing sturdiness of the lower part in lodging of rice (Oryza sativa L.). Plant Prod. Sci. 2005, 8, 166-172. [CrossRef]

7. Busov, V.B.; Brunner, A.M.; Strauss, S.H. Genes for control of plant stature and form. New Phytol. 2008, 177, 589-607. [CrossRef] [PubMed]

8. Achard, P.; Genschik, P. Releasing the brakes of plant growth: How GAs shutdown DELLA proteins. J. Exp. Biol. 2009, 60, 1085-1092. [CrossRef] [PubMed]

9. Swain, S.M.; Singh, D.P. Tall tales from sly dwarves: Novel functions of gibberellins in plant development. Trends Plant Sci. 2005, 10, 123-129. [CrossRef] [PubMed]

10. Yamamuro, C.; Ihara, Y.; Wu, X.; Noguchi, T.; Fujioka, S.; Takatsuto, S.; Ashikari, M.; Kitano, H.; Matsuoka, M. Loss of function of a rice brassinosteroid insensitive1 homolog prevents internode elongation and bending of the lamina joint. Plant Cell 2000, 12, 1591-1605. [CrossRef] 
11. Nakagawa, H.; Tanaka, A.; Mori, M. Brassinosteroids: A class of plant hormone. In Brassinosteroids: A Class of Plant Hormone; Hayat, S., Ahmad, A., Eds.; Springer: Dordrecht, The Netherlands, 2011; pp. 83-117.

12. Braumann, I.; Dockter, C.; Beier, S.; Himmelbach, A.; Lok, F.; Lundqvist, U.; Skadhauge, B.; Stein, N.; Zakhrabekova, S.; Zhou, R.; et al. Mutations in the gene of the G $\alpha$ subunit of the heterotrimeric G protein are the cause for the brachytic1 semi-dwarf phenotype in barley and applicable for practical breeding. Hereditas 2017, 155, 10. [CrossRef] [PubMed]

13. Weiss, D.; Ori, N. Mechanisms of cross talk between gibberellin and other hormones. Plant Physiol. 2007, 144, 1240-1246. [CrossRef]

14. Bouquin, T.; Meier, C.; Foster, R.; Nielsen, M.E.; Mundy, J. Control of specific gene expression by gibberellin and brassinosteroid. Plant Physiol. 2001, 127, 450-458. [CrossRef] [PubMed]

15. Berry, P.; Sterling, M.; Spink, J.; Baker, C.; Sylvester-Bradley, R.; Mooney, S.; Tams, A.; Ennos, A. Understanding and reducing lodging in cereals. Adv. Agron. 2004, 84, 215-269. [CrossRef]

16. Jones, L.; Ennos, A.R.; Turner, S.R. Cloning and characterization of irregular xylem4 (irx4): A severely lignin-deficient mutant of Arabidopsis. Plant J. 2001, 26, 205-216. [CrossRef]

17. Tanaka, K.; Murata, K.; Yamazaki, M.; Onosato, K.; Miyao, A.; Hirochika, H. Three distinct rice cellulose synthase catalytic subunit genes required for cellulose synthesis in the secondary wall. Plant Physiol. 2003, 133, 73-83. [CrossRef]

18. Li, G.; Deng, Q.; Li, S.; Wang, S.; Li, P. Correlation analysis between RVA profile characteristics and quality in rice. Zhongguo Shuidao Kexue 2009, 23, 99-102.

19. Wang, C.; Hu, D.; Liu, X.; She, H.; Ruan, R.; Yang, H.; Yi, Z.; Wu, D. Effects of uniconazole on the lignin metabolism and lodging resistance of culm in common buckwheat (Fagopyrum esculentum M.). Field Crops Res. 2015, 180, 46-53. [CrossRef]

20. Xia, H.Y.; Wang, Z.G.; Zhao, J.H.; Sun, J.H.; Bao, X.G.; Christie, P.; Zhang, F.S.; Li, L. Contribution of interspecific interactions and phosphorus application to sustainable and productive intercropping systems. Field Crops Res. 2013, 154, 53-64. [CrossRef]

21. Peng, D.; Chen, X.; Yin, Y.; Lu, K.; Yang, W.; Tang, Y.; Wang, Z. Lodging resistance of winter wheat (Triticum aestivum L.): Lignin accumulation and its related enzymes activities due to the application of paclobutrazol or gibberellin acid. Field Crops Res. 2014, 157, 1-7. [CrossRef]

22. Sun, Q.; Liu, X.; Yang, J.; Liu, W.; Du, Q.; Wang, H.; Fu, C.; Li, W.X. MicroRNA528 affects lodging resistance of maize by regulating lignin biosynthesis under nitrogen-luxury conditions. Mol. Plant 2018, 11, 806-814. [CrossRef]

23. Ji, H.; Han, C.-d.; Lee, G.-S.; Jung, K.-H.; Kang, D.-Y.; Oh, J.; Oh, H.; Cheon, K.-S.; Kim, S.L.; Choi, I.; et al. Mutations in the microRNA172 binding site of SUPERNUMERARY BRACT (SNB) suppress internode elongation in rice. Rice 2019, 12, 62. [CrossRef] [PubMed]

24. Wang, Y.; Li, J. Molecular basis of plant architecture. Annu. Rev. Plant Biol. 2008, 59, 253-279. [CrossRef]

25. Okuno, A.; Hirano, K.; Asano, K.; Takase, W.; Masuda, R.; Morinaka, Y.; Ueguchi-Tanaka, M.; Kitano, H.; Matsuoka, M. New approach to increasing rice lodging resistance and biomass yield through the use of high gibberellin producing varieties. PLoS ONE 2014, 9, e86870. [CrossRef]

26. Fletcher, R.A.; Gilley, A.; Sankhla, N.; Davis, T.D. Triazoles as plant growth regulators and stress protectants. Hortic Rev. 1999, 24, 55-138.

27. Rademacher, W. GROWTH RETARDANTS: Effects on gibberellin biosynthesis and other metabolic pathways. Annu. Rev. Plant Physiol. 2000, 51, 501-531. [CrossRef] [PubMed]

28. Grossmann, K. Plant growth retardants: Their mode of action and benefit for physiological research. In Progress in Plant Growth Regulation: Proceedings of the 14th International Conference on Plant Growth Substances, Amsterdam, The Netherlands, 21-26 July 1991; Karssen, C.M., van Loon, L.C., Vreugdenhil, D., Eds.; Springer: Dordrecht, The Netherlands, 1992; pp. 788-797.

29. Hedden, P.; Phinney, B.O. Comparison of ent-kaurene and ent-isokaurene synthesis in cell-free systems from etiolated shoots of normal and dwarf-5 maize seedlings. Phytochemistry 1979, 18, 1475-1479. [CrossRef]

30. Magome, H.; Nomura, T.; Hanada, A.; Takeda-Kamiya, N.; Ohnishi, T.; Shinma, Y.; Katsumata, T.; Kawaide, H.; Kamiya, Y.; Yamaguchi, S. CYP714B1 and CYP714B2 encode gibberellin 13-oxidases that reduce gibberellin activity in rice. Proc. Natl. Acad. Sci. USA 2013, 110, 1947. [CrossRef]

31. Sakamoto, T.; Miura, K.; Itoh, H.; Tatsumi, T.; Ueguchi-Tanaka, M.; Ishiyama, K.; Kobayashi, M.; Agrawal, G.K.; Takeda, S.; Abe, K.; et al. An overview of gibberellin metabolism enzyme genes and their related mutants in rice. Plant Physiol. 2004, 134, 1642. [CrossRef]

32. Qin, X.; Liu, J.H.; Zhao, W.S.; Chen, X.J.; Guo, Z.J.; Peng, Y.L. Gibberellin 20-oxidase gene OsGA20ox3 regulates plant stature and disease development in rice. Mol. Plant Microbe Interact. 2013, 26, 227-239. [CrossRef] [PubMed]

33. Xu, Y.; Jia, Q.; Zhou, G.; Zhang, X.-Q.; Angessa, T.; Broughton, S.; Yan, G.; Zhang, W.; Li, C. Characterization of the sdw1 semi-dwarf gene in barley. BMC Plant Biol. 2017, 17, 11. [CrossRef]

34. Spielmeyer, W.; Ellis, M.H.; Chandler, P.M. Semidwarf ( $s d-1)$, "green revolution" rice, contains a defective gibberellin 20-oxidase gene. Proc. Natl. Acad. Sci. USA 2002, 99, 9043. [CrossRef]

35. Sasaki, A.; Ashikari, M.; Ueguchi-Tanaka, M.; Itoh, H.; Nishimura, A.; Swapan, D.; Ishiyama, K.; Saito, T.; Kobayashi, M.; Khush, G.S.; et al. A mutant gibberellin-synthesis gene in rice. Nature 2002, 416, 701-702. [CrossRef] [PubMed]

36. Peng, J.; Carol, P.; Richards, D.E.; King, K.E.; Cowling, R.J.; Murphy, G.P.; Harberd, N.P. The Arabidopsis GAI gene defines a signaling pathway that negatively regulates gibberellin responses. Genes Dev. 1997, 11, 3194-3205. [CrossRef] [PubMed] 
37. Peng, J.; Richards, D.E.; Hartley, N.M.; Murphy, G.P.; Devos, K.M.; Flintham, J.E.; Beales, J.; Fish, L.J.; Worland, A.J.; Pelica, F.; et al. 'Green revolution' genes encode mutant gibberellin response modulators. Nature 1999, 400, 256-261. [CrossRef]

38. Ikeda, A.; Ueguchi-Tanaka, M.; Sonoda, Y.; Kitano, H.; Koshioka, M.; Futsuhara, Y.; Matsuoka, M.; Yamaguchi, J. Slender rice, a constitutive gibberellin response mutant, is caused by a null mutation of the SLR1 gene, an ortholog of the height-regulating gene GAI/RGA/RHT/D8. Plant Cell 2001, 13, 999-1010. [CrossRef]

39. Ogawa, M.; Kusano, T.; Katsumi, M.; Sano, H. Rice gibberellin-insensitive gene homolog, OsGAI, encodes a nuclear-localized protein capable of gene activation at transcriptional level. Gene 2000, 245, 21-29. [CrossRef]

40. Chandler, P.M.; Marion-Poll, A.; Ellis, M.; Gubler, F. Mutants at the Slender1 locus of barley cv himalaya. molecular and physiological characterization. Plant Physiol. 2002, 129, 181. [CrossRef]

41. Peng, J.; Harberd, N.P. Derivative Alleles of the Arabidopsis Gibberellin-Insensitive (gai) Mutation Confer a Wild-Type Phenotype. Plant Cell 1993, 5, 351-360. [CrossRef]

42. Tong, H.; Xiao, Y.; Liu, D.; Gao, S.; Liu, L.; Yin, Y.; Jin, Y.; Qian, Q.; Chu, C. Brassinosteroid regulates cell elongation by modulating gibberellin metabolism in rice. Plant Cell 2014, 26, 4376-4393. [CrossRef]

43. Ueguchi-Tanaka, M.; Fujisawa, Y.; Kobayashi, M.; Ashikari, M.; Iwasaki, Y.; Kitano, H.; Matsuoka, M. Rice dwarf mutant d1, which is defective in the alpha subunit of the heterotrimeric $G$ protein, affects gibberellin signal transduction. Proc. Natl. Acad. Sci. USA 2000, 97, 11638-11643. [CrossRef]

44. Lo, S.F.; Yang, S.Y.; Chen, K.T.; Hsing, Y.I.; Zeevaart, J.A.D.; Chen, L.J.; Yu, S.M. A novel class of gibberellin 2-oxidases control semidwarfism, tillering, and root development in rice. Plant Cell 2008, 20, 2603-2618. [CrossRef] [PubMed]

45. Xie, Z.; Zhang, Z.; Zou, X.; Yang, G.; Komatsu, S.; Shen, Q.J. Interactions of two abscisic-acid induced WRKY genes in repressing gibberellin signaling in aleurone cells. Plant J. 2006, 46, 231-242. [CrossRef] [PubMed]

46. Kang, S.M.; Kim, J.T.; Hamayun, M.; Hwang, I.C.; Khan, A.L.; Kim, Y.H.; Lee, J.H.; Lee, I.J. Influence of prohexadione-calcium on growth and gibberellins content of Chinese cabbage grown in alpine region of South Korea. Sci. Hortic. 2010, 125, 88-92. [CrossRef]

47. Adams, R.; Kerber, E.; Pfister, K.; Weiler, E.W. Studies on the Action of the New Growth Retardant CGA 163 '935 (Cimectacarb); Springer: Dordrecht, The Netherlands, 1992; pp. 818-827.

48. Colebrook, E.H.; Thomas, S.G.; Phillips, A.L.; Hedden, P. The role of gibberellin signalling in plant responses to abiotic stress. J. Exp. Biol. 2014, 217, 67-75. [CrossRef]

49. Gruszka, D. Exploring the brassinosteroid signaling in monocots reveals novel components of the pathway and implications for plant breeding. Int. J. Mol. Sci. 2020, 21, 354. [CrossRef]

50. Fujita, S.; Ohnishi, T.; Watanabe, B.; Yokota, T.; Takatsuto, S.; Fujioka, S.; Yoshida, S.; Sakata, K.; Mizutani, M. Arabidopsis CYP90B1 catalyses the early C-22 hydroxylation of C27, C28 and C29 sterols. Plant J. 2006, 45, 765-774. [CrossRef] [PubMed]

51. Fujioka, S.; Takatsuto, S.; Yoshida, S. An early C-22 oxidation branch in the brassinosteroid biosynthetic pathway. Plant Physiol. 2002, 130, 930-939. [CrossRef]

52. Bajguz, A.; Chmur, M.; Gruszka, D. Comprehensive overview of the brassinosteroid biosynthesis pathways: Substrates, products, inhibitors, and connections. Front. Plant Sci. 2020, 11, 1034. [CrossRef]

53. Nakamura, A.; Fujioka, S.; Sunohara, H.; Kamiya, N.; Hong, Z.; Inukai, Y.; Miura, K.; Takatsuto, S.; Yoshida, S.; Ueguchi-Tanaka, M.; et al. The role of OsBRI1 and its homologous genes, OsBRL1 and OsBRL3, in rice. Plant Physiol. 2006, 140, 580-590. [CrossRef]

54. Li, D.; Wang, L.; Wang, M.; Xu, Y.Y.; Luo, W.; Liu, Y.J.; Xu, Z.H.; Li, J.; Chong, K. Engineering OsBAK1 gene as a molecular tool to improve rice architecture for high yield. Plant Biotechnol. J. 2009, 7, 791-806. [CrossRef]

55. Koh, S.; Lee, S.C.; Kim, M.K.; Koh, J.H.; Lee, S.; An, G.; Choe, S.; Kim, S.R. T-DNA tagged knockout mutation of rice OsGSK1, an orthologue of Arabidopsis BIN2, with enhanced tolerance to various abiotic stresses. Plant Mol. Biol. 2007, 65, 453-466. [CrossRef] [PubMed]

56. Bai, M.-Y.; Zhang, L.-Y.; Gampala, S.S.; Zhu, S.-W.; Song, W.-Y.; Chong, K.; Wang, Z.-Y. Functions of OsBZR1 and 14-3-3 proteins in brassinosteroid signaling in rice. Proc. Natl. Acad. Sci. USA 2007, 104, 13839-13844. [CrossRef] [PubMed]

57. Singh, A.; Breja, P.; Khurana, J.P.; Khurana, P. Wheat Brassinosteroid-Insensitive1 (TaBRI1) interacts with members of TaSERK gene family and cause early flowering and seed yield enhancement in Arabidopsis. PLoS ONE 2016, 11, e0153273. [CrossRef] [PubMed]

58. Hedden, P. The genes of the green revolution. Trends Genet. 2003, 19, 5-9. [CrossRef]

59. Singh, A.; Khurana, P. Ectopic expression of Triticum aestivum SERK genes (TaSERKs) control plant growth and development in Arabidopsis. Sci. Rep. 2017, 7, 12368. [CrossRef]

60. Wan, S.M.; Wu, J.-x.; Zhang, Z.; Sun, X.; Lv, Y.; Gao, C.; Ning, Y.; Ma, J.; Guo, Y.; Zhang, Q.; et al. Activation tagging, an efficient tool for functional analysis of the rice genome. Plant Mol. Biol. 2008, 69, 69-80. [CrossRef] [PubMed]

61. Tanaka, A.; Nakagawa, H.; Tomita, C.; Shimatani, Z.; Ohtake, M.; Nomura, T.; Jiang, C.-J.; Dubouzet, J.G.; Kikuchi, S.; Sekimoto, H.; et al. BRASSINOSTEROID UPREGULATED1, encoding a helix-loop-helix protein, is a novel gene involved in brassinosteroid signaling and controls bending of the lamina joint in rice. Plant Physiol. 2009, 151, 669-680. [CrossRef]

62. Wang, L.; Xu, Y.-Y.; Li, J.; Powell, R.A.; Xu, Z.-H.; Chong, K. Transgenic rice plants ectopically expressing AtBAK1 are semi-dwarfed and hypersensitive to 24-epibrassinolide. J. Plant Physiol. 2007, 164, 655-664. [CrossRef]

63. Tong, H.; Liu, L.; Jin, Y.; Du, L.; Yin, Y.; Qian, Q.; Zhu, L.; Chu, C. DWARF AND LOW-TILLERING acts as a direct downstream target of a GSK3/SHAGGY-like kinase to mediate brassinosteroid responses in rice. Plant Cell 2012, 24, 2562-2577. [CrossRef] 
64. Sakamoto, T.; Morinaka, Y.; Ohnishi, T.; Sunohara, H.; Fujioka, S.; Ueguchi-Tanaka, M.; Mizutani, M.; Sakata, K.; Takatsuto, S.; Yoshida, S.; et al. Erect leaves caused by brassinosteroid deficiency increase biomass production and grain yield in rice. Nat. Biotechnol. 2006, 24, 105-109. [CrossRef]

65. Stewart Lilley, J.L.; Gan, Y.; Graham, I.A.; Nemhauser, J.L. The effects of DELLAs on growth change with developmental stage and brassinosteroid levels. Plant J. 2013, 76, 165-173. [CrossRef]

66. Bai, M.-Y.; Shang, J.-X.; Oh, E.; Fan, M.; Bai, Y.; Zentella, R.; Sun, T.-p.; Wang, Z.-Y. Brassinosteroid, gibberellin and phytochrome impinge on a common transcription module in Arabidopsis. Nat. Cell Biol. 2012, 14, 810-817. [CrossRef]

67. Tong, H.; Chu, C. Brassinosteroid signaling and application in rice. J. Genet. Genom. 2012, 39, 3-9. [CrossRef]

68. Hu, X.; Qian, Q.; Xu, T.; Zhang, Y.; Dong, G.; Gao, T.; Xie, Q.; Xue, Y. The U-box E3 ubiquitin ligase TUD1 functions with a heterotrimeric $\mathrm{G} \alpha$ subunit to regulate brassinosteroid-mediated growth in rice. PLoS Genet. 2013, 9, e1003391. [CrossRef]

69. Shimada, A.; Ueguchi-Tanaka, M.; Sakamoto, T.; Fujioka, S.; Takatsuto, S.; Yoshida, S.; Sazuka, T.; Ashikari, M.; Matsuoka, M. The rice SPINDLY gene functions as a negative regulator of gibberellin signaling by controlling the suppressive function of the DELLA protein, SLR1, and modulating brassinosteroid synthesis. Plant J. 2006, 48, 390-402. [CrossRef]

70. De Vleesschauwer, D.; Van Buyten, E.; Satoh, K.; Balidion, J.; Mauleon, R.; Choi, I.-R.; Vera-Cruz, C.; Kikuchi, S.; Höfte, M. Brassinosteroids antagonize gibberellin- and salicylate-mediated root immunity in rice. Plant Physiol. 2012, 158, 1833-1846. [CrossRef]

71. Song, Y.; You, J.; Xiong, L. Characterization of OsIAA1 gene, a member of rice Aux/IAA family involved in auxin and brassinosteroid hormone responses and plant morphogenesis. Plant Mol. Biol. 2009, 70, 297-309. [CrossRef]

72. Liu, F.; Wang, P.; Zhang, X.; Li, X.; Yan, X.; Fu, D.; Wu, G. The genetic and molecular basis of crop height based on a rice model. Planta 2018, 247, 1-26. [CrossRef]

73. Rozhon, W.; Akter, S.; Fernandez, A.; Poppenberger, B. Inhibitors of brassinosteroid biosynthesis and signal transduction. Molecules 2019, 24, 4372. [CrossRef]

74. Asami, T.; Nakano, T.; Nakashita, H.; Sekimata, K.; Shimada, Y.; Yoshida, S. The influence of chemical genetics on plant science: Shedding light on functions and mechanism of action of brassinosteroids using biosynthesis inhibitors. J. Plant Growth Regul. 2003, 22, 336-349. [CrossRef]

75. Oh, K.; Matsumoto, T.; Yamagami, A.; Hoshi, T.; Nakano, T.; Yoshizawa, Y. Fenarimol, a pyrimidine-type fungicide, inhibits brassinosteroid biosynthesis. Int. J. Mol. Sci. 2015, 16, 17273-17288. [CrossRef]

76. Wang, J.M.; Asami, T.; Yoshida, S.; Murofushi, N. Biological evaluation of 5-substituted pyrimidine derivatives as inhibitors of brassinosteroid biosynthesis. Biosci. Biotechnol. Biochem. 2001, 65, 817-822. [CrossRef]

77. Humphreys, J.M.; Chapple, C. Rewriting the lignin roadmap. Curr. Opin. Plant Biol. 2002, 5, 224-229. [CrossRef]

78. Boudet, A.M.; Kajita, S.; Grima-Pettenati, J.; Goffner, D. Lignins and lignocellulosics: A better control of synthesis for new and improved uses. Trends Plant Sci. 2003, 8, 576-581. [CrossRef]

79. Meyermans, H.; Morreel, K.; Lapierre, C.; Pollet, B.; De Bruyn, A.; Busson, R.; Herdewijn, P.; Devreese, B.; Van Beeumen, J.; Marita, J.M. Modifications in lignin and accumulation of phenolic glucosides in poplar xylem upon down-regulation of caffeoyl-coenzyme a O-methyltransferase, an enzyme involved in lignin biosynthesis. J. Biol. Chem. 2000, 275, 36899-36909. [CrossRef]

80. Zhong, R.; Morrison, W.H.; Himmelsbach, D.S.; Poole, F.L.; Ye, Z.-H. Essential role of caffeoyl coenzyme A O-methyltransferase in lignin biosynthesis in woody poplar plants. Plant Physiol. 2000, 124, 563-578. [CrossRef]

81. Nguyen, T.N.; Son, S.; Jordan, M.C.; Levin, D.B.; Ayele, B.T. Lignin biosynthesis in wheat (Triticum aestivum L.): Its response to waterlogging and association with hormonal levels. BMC Plant Biol. 2016, 16, 28. [CrossRef]

82. Fan, L.; Linker, R.; Gepstein, S.; Tanimoto, E.; Yamamoto, R.; Neumann, P.M. Progressive inhibition by water deficit of cell wall extensibility and growth along the elongation zone of maize roots is related to increased lignin metabolism and progressive stelar accumulation of wall phenolics. Plant Physiol. 2006, 140, 603-612. [CrossRef]

83. Ma, Q.H. Characterization of a cinnamoyl-CoA reductase that is associated with stem development in wheat. J. Exp. Bot. 2007, 58, 2011-2021. [CrossRef]

84. Ma, Q.H. Functional analysis of a cinnamyl alcohol dehydrogenase involved in lignin biosynthesis in wheat. J. Exp. Bot. 2010, 61, 2735-2744. [CrossRef] [PubMed]

85. Ma, Q.H.; Luo, H.R. Biochemical characterization of caffeoyl coenzyme A 3-O-methyltransferase from wheat. Planta 2015, 242, 113-122. [CrossRef]

86. Ma, Q.H.; Xu, Y. Characterization of a caffeic acid 3-O-methyltransferase from wheat and its function in lignin biosynthesis. Biochimie 2008, 90, 515-524. [CrossRef]

87. Jouanin, L.; Goujon, T.; de Nada1, V.; Martin, M.T.; Mila, I.; Vallet, C.; Pollet, B.; Yoshinaga, A.; Chabbert, B.; Petit-Conil, M. Lignification in transgenic poplars with extremely reduced caffeic acid O-methyltransferase activity. Plant Physiol. 2000, 123, 1363-1374. [CrossRef] [PubMed]

88. Osakabe, K.; Tsao, C.C.; Li, L.; Popko, J.L.; Umezawa, T.; Carraway, D.T.; Smeltzer, R.H.; Joshi, C.P.; Chiang, V.L. Coniferyl aldehyde 5-hydroxylation and methylation direct syringyl lignin biosynthesis in angiosperms. Proc. Natl. Acad. Sci. USA 1999, 96, 8955-8960. [CrossRef]

89. Kim, B.G.; Lee, Y.; Hur, H.G.; Lim, Y.; Ahn, J.H. Flavonoid 3'-O-methyltransferase from rice: cDNA cloning, characterization and functional expression. Phytochemistry 2006, 67, 387-394. [CrossRef] [PubMed] 
90. Lin, F.Q.; Yamano, G.; Hasegawa, M.; Anzai, H.; Kawasaki, S.; Kodama, O. Cloning and functional analysis of caffeic acid 3-O-methyltransferase from rice (Oryza sativa). J. Pestic. Sci. 2006, 31, 47-53. [CrossRef]

91. Zhou, J.M.; Fukushi, Y.; Wollenweber, E.; Ibrahim, R.K. Characterization of two O-methyltransferase-like genes in barley and maize. Pharm. Biol. 2008, 46, 26-34. [CrossRef]

92. Eudes, A.; Dutta, T.; Deng, K.; Jacquet, N.; Sinha, A.; Benites, V.T.; Baidoo, E.E.; Richel, A.; Sattler, S.E.; Northen, T.R. SbCOMT (Bmr12) is involved in the biosynthesis of tricin-lignin in sorghum. PLoS ONE 2017, 12, e0178160. [CrossRef]

93. Pascual, M.B.; El-Azaz, J.; de la Torre, F.N.; Cañas, R.A.; Avila, C.; Cánovas, F.M. Biosynthesis and metabolic fate of phenylalanine in conifers. Front. Plant Sci. 2016, 7, 1030. [CrossRef]

94. Takeda, Y.; Koshiba, T.; Tobimatsu, Y.; Suzuki, S.; Murakami, S.; Yamamura, M.; Rahman, M.M.; Takano, T.; Hattori, T.; Sakamoto, M. Regulation of CONIFERALDEHYDE 5-HYDROXYLASE expression to modulate cell wall lignin structure in rice. Planta 2017, 246, 337-349. [CrossRef] [PubMed]

95. Soltani, B.M.; Ehlting, J.; Douglas, C.J. Genetic analysis and epigenetic silencing of At4CL1 and At4CL2 expression in transgenic Arabidopsis. Biotechnol. J. 2006, 1, 1124-1136. [CrossRef] [PubMed]

96. Gui, J.; Shen, J.; Li, L. Functional characterization of evolutionarily divergent 4-coumarate: Coenzyme A ligases in rice. Plant Physiol. 2011, 157, 574-586. [CrossRef]

97. Liu, H.; Guo, Z.; Gu, F.; Ke, S.; Sun, D.; Dong, S.; Liu, W.; Huang, M.; Xiao, W.; Yang, G. 4-Coumarate-CoA ligase-like gene OsAAE3 negatively mediates the rice blast resistance, floret development and lignin biosynthesis. Front. Plant Sci. 2017, 7, 2041. [CrossRef] [PubMed]

98. Zhang, K.; Qian, Q.; Huang, Z.; Wang, Y.; Li, M.; Hong, L.; Zeng, D.; Gu, M.; Chu, C.; Cheng, Z. GOLD HULL AND INTERNODE2 encodes a primarily multifunctional cinnamyl-alcohol dehydrogenase in rice. Plant Physiol. 2006, 140, 972-983. [CrossRef]

99. Hirano, K.; Aya, K.; Kondo, M.; Okuno, A.; Morinaka, Y.; Matsuoka, M. OsCAD2 is the major CAD gene responsible for monolignol biosynthesis in rice culm. Plant Cell Rep. 2012, 31, 91-101. [CrossRef]

100. Yang, Q.; He, Y.; Kabahuma, M.; Chaya, T.; Kelly, A.; Borrego, E.; Bian, Y.; El Kasmi, F.; Yang, L.; Teixeira, P. A gene encoding maize caffeoyl-CoA O-methyltransferase confers quantitative resistance to multiple pathogens. Nat. Genet. 2017, 49, 1364. [CrossRef]

101. Wang, G.F.; Balint-Kurti, P.J. Maize homologs of CCoAOMT and HCT, two key enzymes in lignin biosynthesis, form complexes with the NLR Rp1 protein to modulate the defense response. Plant Physiol. 2016, 171, 2166-2177. [CrossRef]

102. Shah, L.; Yahya, M.; Shah, S.M.A.; Nadeem, M.; Ali, A.; Ali, A.; Wang, J.; Riaz, M.W.; Rehman, S.; Wu, W. Improving lodging resistance: Using wheat and rice as classical examples. Int. J. Mol. Sci. 2019, 20, 4211. [CrossRef]

103. Liu, Q.; Luo, L.; Zheng, L. Lignins: Biosynthesis and biological functions in plants. Int. J. Mol. Sci. 2018, 19, 335. [CrossRef]

104. Jessen, D.; Olbrich, A.; Knufer, J.; Kruger, A.; Hoppert, M.; Polle, A.; Fulda, M. Combined activity of LACS1 and LACS4 is required for proper pollen coat formation in Arabidopsis. Plant J. 2011, 68, 715-726. [CrossRef] [PubMed]

105. Berthet, S.; Demont-Caulet, N.; Pollet, B.; Bidzinski, P.; Cézard, L.; Le Bris, P.; Borrega, N.; Hervé, J.; Blondet, E.; Balzergue, S.; et al. Disruption of LACCASE4 and 17 results in tissue-specific alterations to lignification of Arabidopsis thaliana stems. Plant Cell 2011, 23, 1124-1137. [CrossRef] [PubMed]

106. Zhao, Q.; Nakashima, J.; Chen, F.; Yin, Y.; Fu, C.; Yun, J.; Shao, H.; Wang, X.; Wang, Z.-Y.; Dixon, R.A. LACCASE is necessary and nonredundant with PEROXIDASE for lignin polymerization during vascular development in Arabidopsis. Plant Cell 2013, 25, 3976-3987. [CrossRef] [PubMed]

107. Hargrove, T.R.; Cabanilla, V.L. The impact of semidwarf varieties on Asian rice-breeding programs. BioScience 1979, $29,731-735$. [CrossRef]

108. Khush, G.S. Green revolution: Preparing for the 21st century. Genome 1999, 42, 646-655. [CrossRef]

109. Asano, K.; Hirano, K.; Ueguchi-Tanaka, M.; Angeles-Shim, R.B.; Komura, T.; Satoh, H.; Kitano, H.; Matsuoka, M.; Ashikari, M. Isolation and characterization of dominant dwarf mutants, Slr1-d, in rice. Mol. Genet. Genom. 2009, 281, 223-231. [CrossRef]

110. Sazuka, T.; Kamiya, N.; Nishimura, T.; Ohmae, K.; Sato, Y.; Imamura, K.; Nagato, Y.; Koshiba, T.; Nagamura, Y.; Ashikari, M.; et al. A rice tryptophan deficient dwarf mutant, tdd1, contains a reduced level of indole acetic acid and develops abnormal flowers and organless embryos. Plant J. 2009, 60, 227-241. [CrossRef] [PubMed]

111. Gao, J.; Chen, H.; Yang, H.; He, Y.; Tian, Z.; Li, J. A brassinosteroid responsive miRNA-target module regulates gibberellin biosynthesis and plant development. New Phytol. 2018, 220, 488-501. [CrossRef]

112. Castorina, G.; Consonni, G. The Role of Brassinosteroids in Controlling Plant Height in Poaceae: A Genetic Perspective. Int. J. Mol. Sci. 2020, 21, 1191. [CrossRef]

113. Unterholzner, S.J.; Rozhon, W.; Papacek, M.; Ciomas, J.; Lange, T.; Kugler, K.G.; Mayer, K.F.; Sieberer, T.; Poppenberger, B. Brassinosteroids Are Master Regulators of Gibberellin Biosynthesis in Arabidopsis. Plant Cell 2015, 27, 2261-2272. [CrossRef]

114. Lin, H.; Wang, R.; Qian, Q.; Yan, M.; Meng, X.; Fu, Z.; Yan, C.; Jiang, B.; Su, Z.; Li, J.; et al. DWARF27, an iron-containing protein required for the biosynthesis of strigolactones, regulates rice tiller bud outgrowth. Plant Cell 2009, 21, 1512-1525. [CrossRef]

115. Li, Z.; Zhang, X.; Zhao, Y.; Li, Y.; Zhang, G.; Peng, Z.; Zhang, J. Enhancing auxin accumulation in maize root tips improves root growth and dwarfs plant height. Plant Biotechnol. J. 2018, 16, 86-99. [CrossRef]

116. Miao, C.; Xiao, L.; Hua, K.; Zou, C.; Zhao, Y.; Bressan, R.A.; Zhu, J.-K. Mutations in a subfamily of abscisic acid receptor genes promote rice growth and productivity. Proc. Natl. Acad. Sci. USA 2018, 115, 6058. [CrossRef]

117. Shen, H.; Fu, C.; Xiao, X.; Ray, T.; Tang, Y.; Wang, Z.; Chen, F. Developmental control of lignification in stems of lowland switchgrass variety Alamo and the effects on saccharification efficiency. Bioenergy Res. 2009, 2, 233-245. [CrossRef] 
118. Chabannes, M.; Ruel, K.; Yoshinaga, A.; Chabbert, B.; Jauneau, A.; Joseleau, J.-P.; Boudet, A.-M. In situ analysis of lignins in transgenic tobacco reveals a differential impact of individual transformations on the spatial patterns of lignin deposition at the cellular and subcellular levels. Plant J. 2001, 28, 271-282. [CrossRef]

119. Ling, G.; Jianjun, H.; Bin, Z.; Tao, L.; Rui, S.; Ming, Z. Effects of population density on stalk lodging resistant mechanism and agronomic characteristics of maize. Zuowuxuebao 2010, 33, 1688-1695.

120. Feng, H.; Zhang, S.; Ma, C.; Liu, P.; Dong, S.; Zhao, B.; Zhang, J.; Yang, J. Effect of plant density on microstructure of stalk vascular bundle of summer Maize (Zea mays L.) and its characteristics of sap flow. Acta Agron. Sin. 2014, 40, 1435-1442. [CrossRef]

121. Zheng, M.; Chen, J.; Shi, Y.; Li, Y.; Yin, Y.; Yang, D.; Luo, Y.; Pang, D.; Xu, X.; Li, W.; et al. Manipulation of lignin metabolism by plant densities and its relationship with lodging resistance in wheat. Sci. Rep. 2017, 7, 41805. [CrossRef] [PubMed]

122. Moura, J.C.M.S.; Bonine, C.A.V.; De Oliveira Fernandes Viana, J.; Dornelas, M.C.; Mazzafera, P. Abiotic and biotic stresses and changes in the lignin content and composition in plants. J. Integr. Plant Biol. 2010, 52, 360-376. [CrossRef]

123. Liu, S.; Huang, Y.; Xu, H.; Zhao, M.; Xu, Q.; Li, F. Genetic enhancement of lodging resistance in rice due to the key cell wall polymer lignin, which affects stem characteristics. Breed. Sci. 2018, 68, 508-515. [CrossRef]

124. Tan, H.-T.; Shirley, N.J.; Singh, R.R.; Henderson, M.; Dhugga, K.S.; Mayo, G.M.; Fincher, G.B.; Burton, R.A. Powerful regulatory systems and post-transcriptional gene silencing resist increases in cellulose content in cell walls of barley. BMC Plant Biol. 2015, 15, 62. [CrossRef] [PubMed] 